\title{
Proteomic analysis of Nrk gene-disrupted placental tissue cells explains physiological significance of NRK
}

\author{
Kimitoshi Denda ${ }^{1}$, Kanako Ida', Masataka Tanno${ }^{2}$, Kanako Nakao-Wakabayashi' ${ }^{1}$, Masayuki Komada ${ }^{3}$ \\ and Nobuhiro Hayashi ${ }^{*}$ (D)
}

\begin{abstract}
Objective: NRK is a unique X chromosome-linked protein kinase expressed predominantly in placenta. The gene knockout causes placental overgrowth and delayed labor of Nrk-null fetuses from dams in mouse. To clarify unknown mechanisms behind the Nrk-null phenotypes, protein expression profiles were analyzed in the Nrk-null placenta using a high-performance two-dimensional electrophoresis methodology.

Results: Among around 1800 spots detected, we characterized a dozen protein spots whose expression levels were significantly altered in the Nrk-null placenta compared to wild-type. Analyzing these data sets is expected to reflect the difference physiologically in the presence or absence of NRK, facilitating the development of therapeutic strategies.
\end{abstract}

Keywords: Placentomegaly, Dystocia, Breast tumor, Placenta, Protein kinase

\section{Introduction}

Parturition essential for the survival and proliferation of eutherian mammals is considered to be strictly regulated for ensuring the safety of the next-generation descendants $[1,2]$. During pregnancy, the fetus and placenta are most likely to communicate with each other until delivery in seeking the safe and secure opportunity for birth. However, little is known about the shared mechanism that controls communication between the mother and the unborn. By analyzing various single-gene knockout (KO) mice, several candidates of the messaging molecules involved in the negotiation for selecting the best timing of birth have been identified to date [3-9]. One of the most prominent of these candidates is NRK [10].

NRK (NIK-related kinase), highly expressed in the placenta, is a physiologically unique X-encoded Ser/ Thr protein kinase [10-12]. We previously reported that

\footnotetext{
*Correspondence: nhayashi@bio.titech.ac.jp

1 School of Life Science and Technology, Tokyo Institute of Technology, (M6-6) 2-12-1 Ookayama, Meguro-ku, Tokyo 152-8550, Japan

Full list of author information is available at the end of the article
}

the Nrk gene KO causes placental overgrowth, indicating that NRK is a crucial modulator of cell proliferation and development in placental tissues [10]. Furthermore, the Nrk-null fetuses influence the pregnant dam to delay delivery. Together with subsequent work using intrauterine embryonic transfer of Nrk-null fetuses into wildtype (WT) dams [10], these results suggested that NRK is required for mediating one or more unidentified delivery-inducing signals dispatched from the placenta. In addition, we have found that Nrk mutant female mice develop breast tumors frequently, suggesting that NRK is a tumor-suppressor gene [13].

These results tempted us to clarify the molecular mechanisms behind the Nrk-null phenotypes by using proteomic analysis to profile the protein expression of key regulators in the placenta of $\mathrm{Nrk} \mathrm{KO}$ fetuses. We presented herein detailed two-dimensional electrophoresis (2DE) reference maps of the mutant mouse placenta to establish a NRK-connected placental database, available worldwide, that contains information on protein species identified by $2 \mathrm{DE}$. 


\section{Main text}

\section{Experimental methods}

We applied a high-performance 2DE methodology to analyse mouse placenta harvested in the third trimester of pregnancy. Variations in protein expression levels were defined by comparing individual protein spots on the resulting gels. The trophoblast tissue layer samples were subsequently dissected from the whole placenta as in Additional file 1: Figure S1. After treating the samples using a 2-D Clean-Up Kit (GE Healthcare Ltd., UK), protein quantification, isoelectric focusing of proteins, $2 \mathrm{DE}$, gel-staining, and data analysis were performed as described by Wong et al. [14].

\section{Results and discussion}

In Table 1, we calculated the individual average from six independent trials of 2DE (Fig. 1). Although some variations are observed, it is considered that the increase or decrease in protein amount of each spot has been verified. Among several identified proteins whose levels were attenuated in the mutant, annexin A3 and A5 belong to the annexin family composed of functionally diverged $\mathrm{Ca}^{2+}$-dependent membrane phospholipid-bound intracellular proteins [15]. Downregulation of annexin A3 (Spot 5) inhibits growth, migration, invasion, and metastasis of lung cancer cells by suppressing the MEK/ERK signaling pathway [16]. Annexin A3 may be involved in

Table 1 List of mouse placental proteins whose expression differed significantly between control and $\mathrm{Nrk}^{-/-} \mathrm{2DE}^{\mathrm{D}}$ performed on proteins from E18.5 concepti, as identified by LC-MS/MS analysis

\begin{tabular}{|c|c|c|c|c|c|c|c|c|c|}
\hline Spot $\mathrm{Nr}$ & Protein description & Protein entry & Accession & Score & avgMass & seqCover (\%) & Effect size $^{a}$ & SD & $t$ test $(n=6)$ \\
\hline 1 & $\begin{array}{l}\text { Protein } 2210010 \text { C04Rik OS Mus mus- } \\
\text { culus GN 2210010C04Rik PE } 2 \text { SV } 1\end{array}$ & Q9CPN9_MOUSE & Q9CPN9 & 435 & 26422 & 8.10 & -0.710 & 0.653 & 0.009 \\
\hline 2 & $\begin{array}{l}\text { Heat shock protein HSP } 90 \text { beta OS } \\
\text { Mus musculus GN Hsp90ab1 PE } \\
1 \text { SV } 3\end{array}$ & HS90B_MOUSE & P11499 & 102 & 83281 & 3.59 & -0.248 & 0.126 & 0.020 \\
\hline 3 & $\begin{array}{l}\text { Stress } 70 \text { protein mitochondrial OS } \\
\text { Mus musculus GN Hspa9 PE } 1 \text { SV } 3\end{array}$ & GRP75_MOUSE & P38647 & 1030 & 73461 & 39.62 & -0.018 & 0.774 & 0.942 \\
\hline 4 & $\begin{array}{l}\text { Protein Serpinb9f OS Mus musculus } \\
\text { GN Serpinb9f PE } 2 \text { SV } 1\end{array}$ & Q80UK5_MOUSE & Q80UK5 & 535 & 43034 & 16.98 & -0.126 & 0.096 & 0.148 \\
\hline 5 & $\begin{array}{l}\text { Annexin A3 OS Mus musculus GN } \\
\text { Anxa3 PE } 1 \text { SV } 4\end{array}$ & ANXA3_MOUSE & O35639 & 556 & 36384 & 27.24 & 0.127 & 0.169 & 0.062 \\
\hline 6 & $\begin{array}{l}\text { Staphylococcal nuclease domain } \\
\text { containing protein } 1 \text { OS Mus mus- } \\
\text { culus GN Snd1 PE } 1 \text { SV } 1\end{array}$ & SND1_MOUSE & Q78PY7 & 50 & 102,088 & 4.95 & 0.109 & 0.682 & 0.846 \\
\hline $7^{b}$ & - & - & - & - & - & - & -0.285 & 0.555 & 0.492 \\
\hline 8 & $\begin{array}{l}\text { Protein } 2210010 \text { C04Rik OS Mus mus- } \\
\text { culus GN 2210010C04Rik PE } 2 \text { SV } 1\end{array}$ & Q9CPN9_MOUSE & Q9CPN9 & 727 & 26422 & 4.86 & 0.309 & 0.233 & 0.031 \\
\hline 9 & $\begin{array}{l}\text { Pyruvate kinase isozymes M1 M2 OS } \\
\text { Mus musculus GN Pkm PE } 1 \text { SV } 4\end{array}$ & KPYM_MOUSE & P52480 & 3716 & 57845 & 50.66 & -0.272 & 0.498 & 0.294 \\
\hline $10^{b}$ & - & - & - & - & - & - & 0.221 & 0.347 & 0.198 \\
\hline 11 & $\begin{array}{l}\text { Protein disulfide isomerase A5 OS } \\
\text { Mus musculus GN Pdia5 PE } 2 \text { SV } 1\end{array}$ & PDIA5_MOUSE & Q921X9 & 302 & 59267 & 15.67 & 0.666 & 0.816 & 0.116 \\
\hline 12 & $\begin{array}{l}\text { Glutamate dehydrogenase } 1 \text { mito- } \\
\text { chondrial OS Mus musculus GN } \\
\text { Glud1 PE } 1 \text { SV } 1\end{array}$ & DHE3_MOUSE & P26443 & 176 & 61337 & 10.75 & 0.021 & 0.539 & 0.654 \\
\hline 13 & $\begin{array}{l}\text { T complex protein } 1 \text { subunit alpha OS } \\
\text { Mus musculus GN Tcp1 PE } 1 \text { SV } 3\end{array}$ & TCPA_MOUSE & P11983 & 465 & 60449 & 30.22 & 0.217 & 0.271 & 0.208 \\
\hline 14 & $\begin{array}{l}\text { 40S ribosomal protein SA OS Mus } \\
\text { musculus GN Rpsa PE } 1 \text { SV } 4\end{array}$ & RSSA_MOUSE & P14206 & 3256 & 32838 & 47.46 & 0.110 & 0.148 & 0.115 \\
\hline 15 & $\begin{array}{l}\text { Annexin A5 OS Mus musculus GN } \\
\text { Anxa5 PE } 1 \text { SV } 1\end{array}$ & ANXA5_MOUSE & P48036 & 12996 & 35753 & 83.39 & -0.114 & 0.179 & 0.223 \\
\hline 16 & $\begin{array}{l}\text { SPARC OS Mus musculus GN Sparc } \\
\text { PE } 1 \text { SV } 1\end{array}$ & SPRC_MOUSE & P07214 & 126 & 34450 & 11.59 & -0.256 & 0.597 & 0.235 \\
\hline 17 & $\begin{array}{l}\text { Calpain small subunit } 1 \text { OS Mus mus- } \\
\text { culus GN Capns1 PE } 2 \text { SV } 1\end{array}$ & CPNS1_MOUSE & O88456 & 951 & 28463 & 31.97 & -0.068 & 0.303 & 0.531 \\
\hline 18 & $\begin{array}{l}\text { Annexin A2 OS Mus musculus GN } \\
\text { Anxa2 PE } 1 \text { SV } 2\end{array}$ & ANXA2_MOUSE & P07356 & 14770 & 38676 & 67.26 & 0.102 & 0.410 & 0.509 \\
\hline
\end{tabular}

Specified proteins of the $\mathrm{Nr}^{-1-}$ mouse placenta are indicated

a Individual effect size is an average calculated from six independent trials

b The protein spots corresponding spot number 7 and 10 could not be specified 


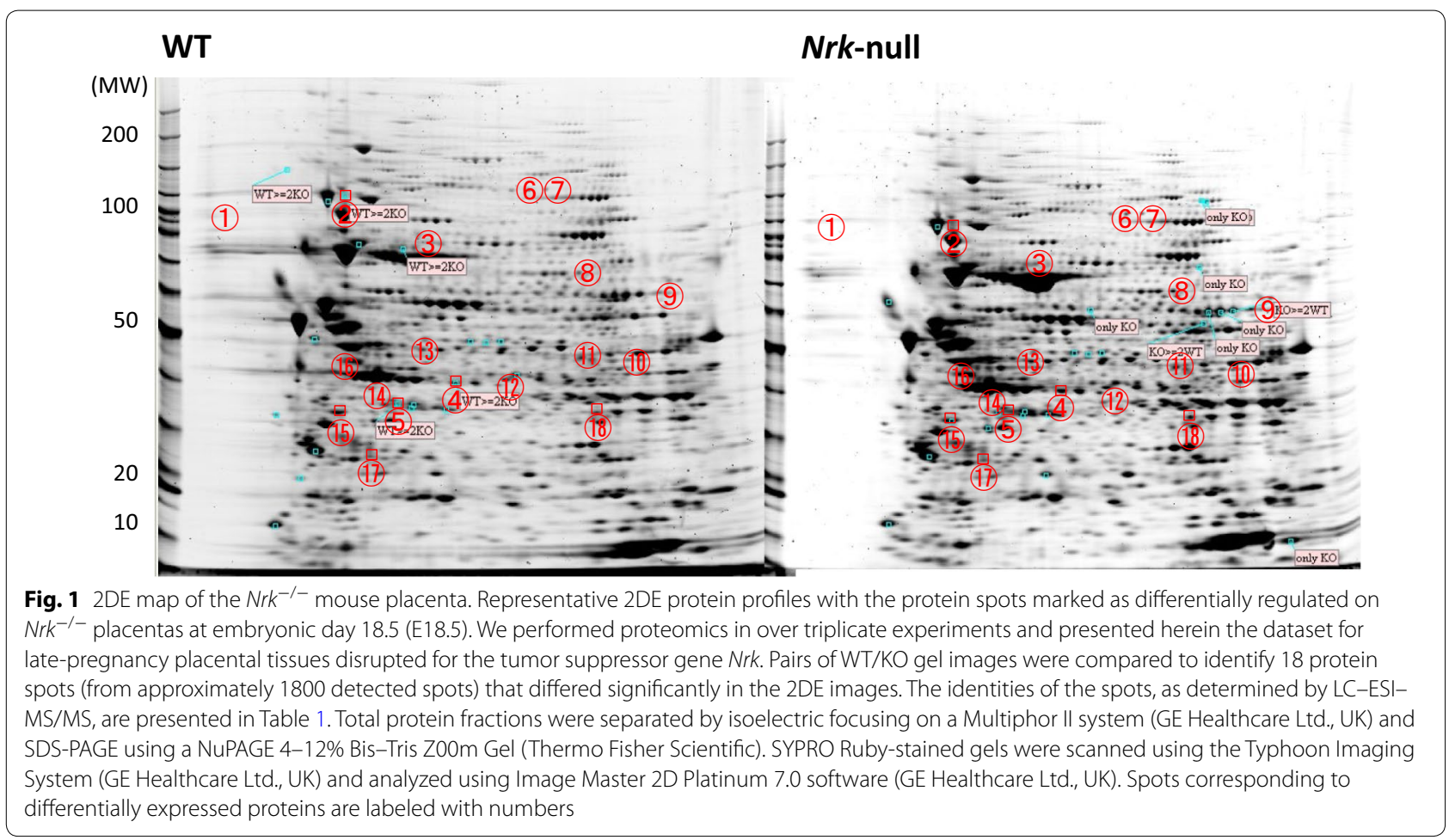

the metabolism of estrogens; this function could be relevant, given that estrogen-induced disruption of the intracellular microenvironment leads to membrane damage and cell cycle arrest [17]. Annexin A5 (Spot 15) is known to be an expedient diagnostic marker for detecting apoptotic cells that is a component of the outer leaflet of the plasma membrane [18]. Decreased levels of Annexin A5 in the Nrk KO placenta tempts us to speculate that NRK functions by potentiating cell death, thereby promoting excess proliferation of specific tissue layers without NRK activity, and leading to phenotypes such as placentomegaly and breast tumorigenesis.

Calpain, a calcium-regulated cysteine protease corresponded to Spot 17, the intensity of which was decreased in the Nrk KO placenta. Calpain is implicated in cytoskeletal remodeling and signal transduction. Calpain-mediated proteolytic cleavage induces cytoskeletal dynamics. This activity is altered during aging and in the progression of numerous diseases, including calcium-dependent disorders and pathological conditions [19, 20]. Spot 2 , a signal decreased in the KO placenta, was identified as HSP90, a molecular chaperone with numerous client proteins. Many HSP90 inhibitors are undergoing study for potential use as clinical therapies [21]. Calpain is known to regulate HSP90 expression by cleaving HSP90 directly. On the other hand, HSP90 has been reported to affect the activity of calpain, suggesting that interactions between HSP90 and calpain jointly contribute to physiological functions. Indeed, genetic disruption of the calpain-encoding gene or treatment with HSP90 inhibitors has been shown to yield attenuation of mammary tumorigenesis [22].

Spot 4, a signal decreased in the KO placenta, corresponded to serpins of clade B (serpinb9f), a unique class of intracellular protease inhibitors [23]. Among these inhibitors, serpin B9 is a well-studied specific inhibitor of granzyme B [24]. It seems likely that the granzyme-mediated proteolysis is important for the immune response to infection or tumorigenesis. Changes in serpin levels are expected to cause cell damage in normal tissues. Therefore, NRK may contribute to a cytoprotective function by safeguarding lymphocytes from granzymes.

For the purposes of the present study, proteomics may be a more informative approach than gene expression (transcriptional) profiling, given that transcript accumulation does not always correlate with qualitative or quantitative differences in protein levels and often fails to reflect in vivo protein localization, depending on the tissue. Our data tempted to speculate that dysfunction of NRK leads to defects in cellular proliferation, cell cycle progression, resistance to apoptosis, and oncogenesis. Also, recent progress in advanced mass spectrometry methods is expected to enable us to monitor numerous phosphorylation sites in proteins. Together with the genomic discoveries through genome-wide association studies reported recently 
[25], further profiling analyses of the gene product changes in the Nrk-gene-mutants is expected to clarify the functional mechanism of fetoplacental development and differentiation during pregnancy, facilitating the identification of potential targets of current chemotherapeutic treatments available for perinatal medicine.

\section{Limitations}

The main limitation of our research was that we couldn't verify why each identified expressed protein decreased in NRK-deficient placental tissue cells which could explain how NRK works physiologically in the state of health. Elucidating the physiological role of NRK in future studies would not only become one target protein for drug discovery but also helps to improve human health.

\section{Supplementary information}

Supplementary information accompanies this paper at https://doi. org/10.1186/s13104-019-4818-7.

Additional file 1: Figure S1. Dissection procedure for collecting layerenriched tissue samples from the mouse whole placenta in late gestation.

\section{Abbreviations}

2DE: two-dimensional gel electrophoresis; dpc: days postcoitum; ER: estrogen receptor; H\&E: hematoxylin and eosin; LC-MS/MS: liquid chromatographytandem mass spectrometry; PCR: polymerase chain reaction; WT: wild-type; KO: knockout.

\section{Acknowledgements}

We thank Isao Kii, and Junji Hirota for discussions; Tsuyoshi Endo, Ken Hirosaki, Kei Ujimoto, and Rina Doi for technical assistance; Naoki Okamoto for help with mouse handling and maintenance. We express our appreciation to the staff of the Center for Biological Resources and Informatics, Tokyo Institute of Technology, for maintenance of the mouse colony. We also thank the Biomaterials Analysis Division, Tokyo Institute of Technology, for DNA analysis.

\section{Authors' contributions}

$\mathrm{KD}, \mathrm{Kl}, \mathrm{KNW}, \mathrm{MK}$ and $\mathrm{NH}$ conceived the study; KD, Kl, KNW, MK and NH generated and analyzed experimental data; MT, MK and NH provided a critical review of the manuscript. All authors read and approved the final manuscript.

\section{Funding}

This work was supported by Grants-in-aid from the Ministry of Education, Culture, Sports, Science, and Technology of Japan (Grants 15K14378 to K. D. and 21113505 to M. K.). The funding bodies played no role in the design of the study and data collection process, analysis, interpretation of data and in writing the manuscript.

\section{Availability of data and materials}

All data generated or analyzed during this study are included in this published article and its supplementary information files.

\section{Ethics approval and consent to participate}

All animal experiments were approved by and performed under the guidelines of the Institutional Animal Care and Research Advisory Committee of Tokyo Institute of Technology.

\section{Consent for publication}

Not applicable.

\section{Competing interests}

The authors declare that they have no competing interests.

\section{Author details}

${ }^{1}$ School of Life Science and Technology, Tokyo Institute of Technology, (M6-6) 2-12-1 Ookayama, Meguro-ku, Tokyo 152-8550, Japan. ${ }^{2}$ Department of Pathology, Tokyo Nishi Tokushukai Hospital, Akishima, Japan. ${ }^{3}$ Cell Biology Unit, Institute of Innovative Research, Tokyo Institute of Technology, Yokohama, Japan.

Received: 5 October 2019 Accepted: 21 November 2019

Published online: 29 November 2019

\section{References}

1. Nathanielsz PW. The timing of birth. Am Sci. 1996;84(6):562-9.

2. Renthal NE, Williams KC, Montalbano AP, Chen CC, Gao L, Mendelson CR. Molecular regulation of parturition: a myometrial perspective. Cold Spring Harb Perspect Med. 2015;5(11):a023069.

3. Uozumi N, Kume K, Nagase T, Nakatani N, Ishii S, Tashiro F, Komagata Y, Maki K, Ikuta K, Ouchi Y, et al. Role of cytosolic phospholipase A2 in allergic response and parturition. Nature. 1997;390(6660):618-22.

4. Sugimoto Y, Yamasaki A, Segi E, Tsuboi K, Aze Y, Nishimura T, Oida H, Yoshida N, Tanaka T, Katsuyama M, et al. Failure of parturition in mice lacking the prostaglandin F receptor. Science. 1997;277(5326):681-3.

5. Reese J, Paria BC, Brown N, Zhao X, Morrow JD, Dey SK. Coordinated regulation of fetal and maternal prostaglandins directs successful birth and postnatal adaptation in the mouse. Proc Natl Acad Sci U S A. 2000;97(17):9759-64.

6. Bond CT, Sprengel R, Bissonnette JM, Kaufmann WA, Pribnow D, Neelands T, Storck T, Baetscher M, Jerecic J, Maylie J, et al. Respiration and parturition affected by conditional overexpression of the $\mathrm{Ca}^{2+}$-activated $\mathrm{K}^{+}$ channel subunit, SK3. Science. 2000;289(5486):1942-6.

7. Reeves CV, Wang X, Charles-Horvath PC, Vink JY, Borisenko VY, Young JA, Kitajewski JK. Anthrax toxin receptor 2 functions in ECM homeostasis of the murine reproductive tract and promotes MMP activity. PLOS ONE. 2012;7(4):e34862.

8. Herington JL, O'Brien C, Robuck MF, Lei W, Brown N, Slaughter JC, Paria $B C$, Mahadevan-Jansen A, Reese J. Prostaglandin-endoperoxide synthase 1 mediates the timing of parturition in mice despite unhindered uterine contractility. Endocrinology. 2018;159(1):490-505.

9. Roizen JD, Asada M, Tong M, Tai HH, Muglia LJ. Preterm birth without progesterone withdrawal in 15-hydroxyprostaglandin dehydrogenase hypomorphic mice. Mol Endocrinol. 2008;22(1):105-12.

10. Denda K, Nakao-Wakabayashi K, Okamoto N, Kitamura N, Ryu JY, Tagawa Y, Ichisaka T, Yamanaka S, Komada M. Nrk, an X-linked protein kinase in the germinal center kinase family, is required for placental development and fetoplacental induction of labor. J Biol Chem. 2011;286(33):28802-10.

11. Kanai-Azuma M, Kanai Y, Okamoto M, Hayashi Y, Yonekawa H, Yazaki K. Nrk: a murine X-linked NIK (Nck-interacting kinase)-related kinase gene expressed in skeletal muscle. Mech Dev. 1999:89(1-2):155-9.

12. Nakano K, Yamauchi J, Nakagawa K, Itoh H, Kitamura N. NESK, a member of the germinal center kinase family that activates the c-Jun N-terminal kinase pathway and is expressed during the late stages of embryogenesis. J Biol Chem. 2000;275(27):20533-9.

13. Yanagawa T, Denda K, Inatani T, Fukushima T, Tanaka T, Kumaki N, Inagaki Y, Komada M. Deficiency of X-linked protein kinase Nrk during pregnancy triggers breast tumor in mice. Am J Pathol. 2016;186(10):2751-60.

14. Wong SY, Hashim OH, Hayashi N. Development of high-performance two-dimensional gel electrophoresis for human hair shaft proteome. PLOS ONE. 2019:14(3):e0213947.

15. Schloer S, Pajonczyk D, Rescher U. Annexins in translational research: hidden treasures to be found. Int J Mol Sci. 2018;19(6):1781.

16. Liu YF, Liu QQ, Zhang YH, Qiu JH. Annexin A3 knockdown suppresses lung adenocarcinoma. Anal Cell Pathol. 2016;2016:4131403.

17. Bajbouj K, Shafarin J, Abdalla MY, Ahmad IM, Hamad M. Estrogen-induced disruption of intracellular iron metabolism leads to oxidative stress, membrane damage, and cell cycle arrest in MCF-7 cells. Tumour Biol. 2017;39(10):1010428317726184. 
18. Ghislat G, Aguado C, Knecht E. Annexin A5 stimulates autophagy and inhibits endocytosis. J Cell Sci. 2012;125(Pt 1):92-107.

19. Chen HH, Liu P, Auger P, Lee SH, Adolfsson O, Rey-Bellet L, LafranceVanasse J, Friedman BA, Pihlgren M, Muhs A, et al. Calpain-mediated tau fragmentation is altered in alzheimer's disease progression. Sci Rep. 2018;8(1):16725

20. Averna M, Pellegrini M, Cervetto C, Pedrazzi M, Bavestrello M, De Tullio R, Salamino F, Pontremoli S, Melloni E. Physiological roles of calpain 1 associated to multiprotein NMDA receptor complex. PLoS ONE. 2015;10(10):e0139750.

21. Hayashi E, Kuramitsu Y, Okada F, Fujimoto M, Zhang X, Kobayashi M, lizuka N, Ueyama Y, Nakamura K. Proteomic profiling for cancer progression: differential display analysis for the expression of intracellular proteins between regressive and progressive cancer cell lines. Proteomics. 2005;5(4):1024-32.

22. Grieve S, Gao Y, Hall C, Hu J, Greer PA. Calpain genetic disruption and HSP90 inhibition combine to attenuate mammary tumorigenesis. Mol Cell Biol. 2016;36(15):2078-88
23. Gatto M, laccarino L, Ghirardello A, Bassi N, Pontisso P, Punzi L, Shoenfeld $Y$, Doria A. Serpins, immunity and autoimmunity: old molecules, new functions. Clin Rev Allergy Immunol. 2013;45(2):267-80.

24. van der Burgh R, Meeldijk J, Jongeneel L, Frenkel J, Bovenschen N, van Gijn M, Boes M. Reduced serpinB9-mediated caspase-1 inhibition can contribute to autoinflammatory disease. Oncotarget. 2016;7(15):19265-71.

25. Zhang G, Srivastava A, Bacelis J, Juodakis J, Jacobsson B, Muglia LJ. Genetic studies of gestational duration and preterm birth. Best Pract Res Clin Obstet Gynaecol. 2018:52:33-47.

\section{Publisher's Note}

Springer Nature remains neutral with regard to jurisdictional claims in published maps and institutional affiliations.
Ready to submit your research? Choose BMC and benefit from:

- fast, convenient online submission

- thorough peer review by experienced researchers in your field

- rapid publication on acceptance

- support for research data, including large and complex data types

- gold Open Access which fosters wider collaboration and increased citations

- maximum visibility for your research: over 100M website views per year

At BMC, research is always in progress.

Learn more biomedcentral.com/submissions 